\title{
ANALISIS DAMPAK JIKA REDENOMINASI DILAKUKAN: PENGARUHNYA TERHADAP DAYA BELI MASYARAKAT INDONESIA
}

\author{
Kartika Dewi \\ Accounting and Finance Department, Faculty of Economics and Communication, BINUS University \\ Jln. K. H. Syahdan No. 9, Palmerah, Jakarta Barat 11480 \\ kartika.dewi@binus.ac.id
}

\begin{abstract}
The government of Indonesia has approved Bank Indonesia to redenominated Rupiah currency by eliminating three zeros starting 2011 until 2020. The Law itself is still waiting an approval from Right and Human Right Ministry then passed by the House of Representatives. The problem occurs when Rupiah Redenomination will make purchasing power lower for most Indonesia. There are many pros and contras about this plan. Opponents claimed it will make the economy worse. On the other hand, Proponents can wait to see Rupiah will have the same value with other currencies, boost up rupiah credibility in international. Writer wants to analyze this plan from purchasing power for Indonesian when the program will be implemented this year 2013. Of course, it will have positive side as well as negative side. The fact that the prices for goods and services always increase each month and those increases will accumulated at the end of the year will result significant increase. This big increase will result big inflation. The truth is inflation is rising up in Indonesia everyday . Government told inflation is under control but most Indonesian is getting suffered with this price increase. Most people can not afford for basic necessities. Businessmen tried to increase their employess salaries and wages but the increase is smaller than its goods pricess in results the increase in salary and wage can not cover the prices hike for goods. Journal is made by collecting information through internet, simple questioners with students and employes with Binus University campus,text-books, own experiences as Indonesian citizen.Then writer drawn a conclusion and suggestions. The result from this research based on simple questioner is disagreement on Rupiah Redenomination. At the end, writer concludes that Indonesia needs good moral citizens who can make a drastic change for Indonesian' sake.
\end{abstract}

Keywords: redenomination Rupiah, inflation, sanering, purchasing power

\section{ABSTRAK}

Pengumuman Bank Indonesia untuk meredenominasi Rupiah mengundang banyak kritik dan pujian. Masalah yang terjadi pada saat pelaksanaan redenominasi adalah penurunan daya beli masyarakat Indonesia. Bagi yang anti redenominasi telah memaparkan keburukan-keburukan yang bakal terjadi bila program tersebut dilaksanakan, Di lain pihak, bagi para pendukung,mereka menyambut baik rencana ini karena merasa hal ini akan mengangkat derajat Indonesia di mata dunia. Terlepas dari pro dan kontra, rencana redenominasi bila diamati dari sisi daya beli masyarakat bila program ini dilaksanakan,kemungkinan buruk dan baik yang akan terjadi. Kenyataan yang terjadi di masyarakat adalah harga-harga barang/jasa selalu naik setiap bulan.Kenaikan yang terjadi tiap bulan tidak besar tetapi bila kenaikan barang tersebut diakumulasikan dalam setahun maka kita tentu akan heran,begitu besarnya persentase kenaikan tersebut.Dengan kata lain inflasi selalu terjadi di Indonesia meskipun laporan pemerintah selalu mengatakan inflasi kita aman terkendali tetapi kenyataannya masyarakat selalu mengeluh gaji mereka tidak cukup untuk membeli kehidupan yang layak. Pengusaha pun dihadapkan pada lingkaran setan yang tak ada ujungnya, menaikkan upah buruh dengan maksud karyawannya menjadi sedikit lebih makmur tetapi harga barang/jasa naik lebih tinggi ketimbang upah gajinya akhirnya kenaikan gaji tidak cukup untuk membeli kelayakan hidup.Penulisan dibuat dengan cara mengumpulkan informasi melalui internet,tanya jawab dengan mahasiswa dan karyawan,buku text,pengalaman pribadi sebagai Warga Negara Indonesia dan ditarik kesimpulan dan saran. Hasil penelitian ini adalah ketidaksetujuan responden bila pemerintah menerapkan redenominasi Rupiah. Pada akhhir tulisan ini penulis menyimpulkan dibutuhkan manusia yang berkarakter baik untuk memajukan negara Indonesia.

Kata kunci: redenominasi Rupiah, inflasi, sanering, daya beli 


\section{PENDAHULUAN}

Penulis tertarik dengan masalah redenominasi Rupiah yang menghangat akhir-akhir ini, dan sering dibahas sisi positif dan negatifnya. Oleh karena itu, penulis ingin menyelidiki masalah ini dari sudut pandang penulis berdasarkan fakta yang ada, teori yang tersedia di buku, dan sejarah perekonomian Indonesia pada masa terjadinya sanering hingga 2012. Penulisan dititikberatkan pada daya beli masyarakat bila redenominasi diberlakukan. Tujuan penelitian adalah untuk mengetahui jika responden mengetahui rencana redenominasi yang akan dilakukan pemerintah dan efek yang terjadi bila redenominasi diberlakukan.

Hasil Riset Bank Dunia mengatakan digit Rupiah berada di urutan ke-2 dunia setelah Vietnam. Hal itu membuat Bank Indonesia merencanakan redenominasi Rupiah pada 3 Agustus 2010. Menurut mereka redenominasi perlu dilakukan untuk meyederhanaan transaksi keuangan. Redenominasi dilakukan dengan memangkas tiga digit nol. Contohnya, Rp 1.000 menjadi Rp 1; Rp 1.000.000 menjadi Rp 1.000. Pada 2013 pecahan terbesar yang dimiliki Negara Republik Indonesia adalah uang kertas Rupiah 100.000. Ini merupakan pecahan terbesar kedua setelah negara Vietnam yang mempunyai pecahan 500.000 Dong Vietnam. (Anonim, 2011)

Dengan mengambil pengalamanan dari negara-negara yang sudah pernah melakukan redenominasi mata uang, maka Indonesia mengambil langkah yang berani untuk mengikutinya. Contoh negara yang berhasil melakukan redenominasi mata uangnya adalah Turki yang menghilangkan enam digit nol di 2005. Ada juga negara Bulgaria yang sukses melakukan redenominasi, tetapi beberapa negara gagal seperti Zimbabwe, Brazil, Argentina, dan Rusia. Kisah sukses negara lain yang melakukan redenominasi mata uangnya akan dibahas pada paragraf selanjutnya.

Berdasarkan Farlex Financial Dictionary (2013):

"Redenomination Currency is the process of changing the face value of banknotes or coins used in the circulation currency. Currency redenomination is a public policies measure that simplifies the understanding, use and managing of the national currency through its expression in a new and smaller equivalent scale."

Atau dengan kata lain, bahwa redenominasi merupakan proses pemangkasan atau penyederhanaan mata uang yang dimaksudkan untuk mempermudah transaksi. Menurut Ensiklopedia Bahasa Indonesia, Redenominasi berarti pemotongan mata uang menjadi lebih kecil tanpa mengubah nilai tukarnya. Penulisan artikel jurnal ini dilakukan untuk memastikan masyarakat dan pembaca mempunyai informasi yang akurat terkini mengenai rencana redenominasi rupiah serta dampaknya terhadap daya beli masyarakat jika redenominasi ini telah diterapkan.

\section{METODE PENELITIAN}

Penelitian dilakukan dengan cara kualitatif dengan melihat fakta yang ada di kehidupan masyarakat sehari-hari, misalnya: membandingkan harga-harga barang kebutuhan pokok sehari-hari dari 1990 hingga 2012, membandingkan teori mengenai redenominasi dan inflasi yang ada dalam buku teks, melakukan tanya jawab sederhana ke mahasiswa dan karyawan di kampus Binus Alam Sutra, tinjauan pustaka mengenai keberhasilan negara lain khususnya Turki dalam melakukan redenominasi, tinjauan pustaka mengenai sejarah sanering di Indonesia. Akhirnya, penarikan simpulan mengenai pendapat penulis. 


\section{HASIL DAN PEMBAHASAN}

Berita Redenominasi semakin menghangat awal Januari 2013. Banyak masyarakat menjadi resah dan bingung karena pemerintah mengumumkan redenominasi mata uang Rupiah. Redenominasi ini dimaksudkan untuk menyederhanakan transaksi, tetapi penyederhanaan tersebut tidak mengurangi nilai mata uang sehingga rakyat tetap mempunyai daya-beli (purchasing power) yang sama. Pemerintah mengusulkan proses redenominasi ini selesai hingga 2020.

Adapun rencana yang akan dijalankan (Hutauruk, 2011) adalah: (1) 2011-2012: tahap sosialisasi; dalam tahap ini Bank Indonesia mensosialisasikan redenominasi kepada masyarakat, meyakinkan masyarakat bahwa redenominasi rupiah berbeda dengan sanering. Sistem akuntansi dan informasi akan disesuaikan bertahap juga. (2) 2013-2015: tahap transisi; dalam tahap ini Bank Indonesia akan menerbitkan pecahan yang baru yang nilainya 1/1000 kali uang lama. Uang baru yang dicetak akan diberi tanda "UANG BARU". Dalam tahap ini semua barang akan diberi 2 harga yaitu harga baru dan harga lama. (3) 2016-2018: tahap penarikan uang lama; dalam tahap ini Bank Indonesia akan menarik semua uang lama dan diakhir tahun 2018 tidak akan ada lagi uang lama yang beredar. (4) 2019-2020: tahap pemantapan; dalam tahap ini Bank Indonesia akan menghapus tulisan "UANG BARU"di kertas uang dan menggantikan uang design baru tanpa kata-kata UANG BARU. Diharapkan pada 2021 semua uang telah menjadi uang baru, dan tidak ada lagi uang lama yang akan beredar.

\section{Faktor yang Memengaruhi Redenominasi}

Pertama adalah banyaknya digit nol saat ini. Ilustrasinya adalah pada saat transaksi membeli 1 unit mobil standar seharga Rp 204.897.550; total digit adalah 9. Hal itu akan menjadi kompleks bagi perusahaan menghitung transaksi bila total penjualan mencapai 100.000 unit. Para investor luar negeri merasa kesulitan dalam melakukan penghitungan nilai triliun rupiah. Ditambah lagi, kapasitas mesin dalam menghitung triliunan juga terbatas. Perampingan nol sebanyak 3 digit diharapkan akan mempermudah transaksi.

Kedua adalah inflasi yang tinggi di Indonesia. Inflasi secara umum adalah kenaikan terusmenerus terhadap harga barang/jasa yang ada di pasar akibat dari ketidakseimbangan arus barang dan arus uang. Dampak dari inflasi adalah: harga barang/jasa naik terus, jumlah uang yang beredar meningkat, nilai mata uang menurun, distribusi barang tidak lancer. Inflasi mempunyai dampak positif dan negatif bagi suatu negara. Dampak positif adalah banyaknya kesempatan bekerja di pabrik karena investasi modal meningkat, akibatnya jumlah kuantitas barang meningkat, peredaran barang menjadi cepat, keuntungan para pengusaha bertambah banyak. Sedangkan dampak negatif dari inflasi adalah harga barang/jasa naik, masyarakat malas menabung karena suku bunga bank rendah, spekulasi dan kepercayaan masyarakat terhadap mata uang menurun. Ada 6 hal yang menyebabkan terjadinya inflasi adalah ekspor-impor, tabungan dan investasi, penerimaan dan pengeluaran negara. Jika terjadi keseimbangan(balance) untuk ke-6 sektor tesebut, tidak akan terjadi inflasi.

Dalam pembahasan ini peneliti ingin berbagi pengetahuan tentang konsep inflasi berdasarkan pengalaman yang dialami. Kembali di 1990 saat peneliti masih berkuliah di salah satu Perguruan Tinggi Swasta di Jakarta, peneliti saat itu harus kos karena kampung halaman bukan Jakarta. Untuk makan, peneliti harus membeli nasi dan lauk di kantin kampus, dan mengeluarkan uang Rp 1250-1500 untuk mendapat nasi dan 3 lauk pilihan. Pada 2012 di kantin kampus yang sama, peneliti harus membayar Rp 12.000 untuk nasi dan 3 lauk. Dalam waktu 22 tahun harga telah naik 10x lipat, atau $10 \times 100 \%=1000 \%$. Telah terjadi $1000 \%$ inflasi untuk nasi dan3 lauk di tempat yang sama dalam waktu 22 tahun. Untuk masalah transportasi, di 1990 peneliti hanya menbayar Rp 100 untuk naik bus kota dan sekarang di 2012 penulis harus membayar Rp 2000-3500 untuk bus kota. Dalam kurun waktu 
22 tahun telah terjadi kenaikan minimum 20x lipat atas jasa yang sama, atau 20x100\% $=2000 \%$ inflasi untuk jasa bus kota dengan bus yang sama, yang masih digunakan sampai saat ini dalam waktu 22 tahun.

Setelah menyelesaikan studi di Amerika Serikat, peneliti kembali pada 2003. Pada 2012, harga sayur yang sama per ikat menjadi Rp 2000-2500. Peneliti hanya membutuhkan Rp 50.000 di 2003 untuk membeli bahan kebutuhan makanan yang mencukupi gizi 4 sehat 5sempurna. Di 2012 diperlukan Rp 200.000 untuk barang yang sama. Dalam kurun waktu 9 tahun telah terjadi kenaikan 4x lipat atas barang yang sama. Data inflasi yang dikeluarkan dari berbagai sumber pemerintahan selalu menyebutkan kurang dari $10 \%$ per tahun, tetapi bila dilihat harga secara riil, inflasi yang sesungguhnya lebih dari $10 \%$. Nilai mata uang rupiah secara riil menyusut menjadi kecil setiap tahun, kita harus mengeluarkan uang yang lebih banyak lagi untuk mendapat barang yang sama. Hal ini sungguh merugikan bagi masyarakat yang mempunyai penghasilan tetap, dengan kenaikan gaji lebih kecil ketimbang kenaikan inflasi terselubung ini.

Pada 16 Februari 2013, penulis mencoba membuat kuesioner sederhana kepada sejumlah karyawan, mahasiswa lingkungan kampus Binus Alam Sutra, tetangga rumah, mengenai informasi/pengetahuan mereka tentang redenominasi. Hasilnya, 99\% tidak tahu tentang redenominasi. Mereka hanya tahu dari cerita-cerita lucu seputar redenominasi yang ada di BlackBerry. Hal ini menunjukkan kebiasaan membaca di masyarakat sangat kurang, padahal isu ini telah sering kali dibahas di koran. Sebagai catatan, mereka yang menjadi responden adalah masyarakat perkotaan dan menerima pendidikan kuliah.

Ketiga adalah ingin terlihat lebih bermartabat dan memiliki kredibelitas sehingga menunjukkan landasan perekonomian yang kuat. Dengan dilakukan redenominasi, nilai Rupiah akan pendek, tidak terlalu banyak digit. Sehingga jumlah digit akan sama dengan negara-negara lain. Misalnya untuk membeli secangkir kopi di pusat perbelanjaan, harga lama adalah Rp 20.000 maka sekarang cukup membayar Rp 20. Harga ini sesuai dengan RM 5, Sing Dollar 10, USD 4. Jumlahnya hanya berkisar 1-20 saja.

\section{Dampak Positif Redenominasi}

Pertama, transaksi keuangan menjadi lebih sederhana, tidak terlalu banyak digit, dan mempercepat perhitungan transaksi karena digit lebih sedikit; contohnya penggunaan argo taksi, pembelian bensin di pom bensin. Kedua, mempermudah akuntansi keuangan. Karena keterbatasan penyimpanan data di mesin, penyerderhanaan rupiah sangat membantu untuk menghemat waktu, mengurangi kesalahan membaca laporan keuangan yang sering disajikan dalam jutaan rupiah, mempermudah perhitungan data statistiknya untuk analisa laporan akuntansi. Ketiga, meningkatkan martabat bangsa Indonesia di mata Internasional. Untuk masyarakat yang bekerja dengan berkolaborasi dengan perusahaan asing, atau bermitra dengan investor asing, hal ini mempunyai dampak positif karena dengan ringkasnya mata uang rupiah akan mengangkat citra Indonesia. Untuk penduduk Indonesia yang tidak bermitra dengan perusahaan asing tentunya tidak berdampak dari redenominasi ini. Kita ambil contoh, 1 USD = Rp 9.650 (per 20 Februari) setelah redenominasi 1USD $=\mathrm{Rp}$ 9, menimbulkan kesan nilai Dolar tidak terlalu tinggi terhadap Rupiah memberikan dampak positif kepada investor asing.

\section{Dampak Negatif Redenominasi}

Pertama, penggantian mesin ATM, kasir, dan registrasi. Semua mesin yang selama ini telah diproses menggunakan digit yang banyak harus disesuaikan. Ukuran uang kertas jika berubah akan mengubah suku cadang yang ada di mesin ATM. Meskipun mesin yang lama dapat digunakan tetapi butuh pemrograman ulang. Hal ini membuat pengeluaran kas yang tidak perlu, pengeluaran tambahan 
bagi para pengusaha. Pengusaha/pihak swasta adalah yang terbeban. Ujung-ujungnya harga eceran dinaikkan demi menutupi biaya alih informasi ini.

Kedua, sosialisasi terhadap masyarakat. Indonesia adalah negara kepulauan dengan penduduk 245 juta per akhir 2012. Sebagian penduduk Indonesia adalah petani, pelaut yang nota bene "terbelakang" dalam hal pendidikan dan informasi. Diperlukan kerjasama dengan pemerintah daerah dalam sosisalisasi redenominasi ini. Dibutuhkan waktu yang lama, tenaga ahli/tim sukses yang dapat meyakinkan masyarakat didaerah pelosok. Pemerintah harus menggaji para tenaga ahli untuk meyakinkan masyarakat golongan ini. Artinya, pemerintah harus mengeluarkan biaya tambahan. Tim sukses sosialisasi ini tidak semata-mata untuk penduduk daerah pelosok, tetapi daerah perkotaan juga membutuhkan informasi yang jelas karena kesuksesan Redenominasi Rupiah ini terletak pada sosialisasi informasi yang akurat dan terpercaya.

Ketiga, biaya iklan yang ditanggung oleh pemerintah akan meningkat akibat sosialisasi tersebut. Contohnya adalah iklan di televisi, majalah, koran, baliho di jalanan dan radio. Menyamakan persepsi pemerintah dengan masyarakat 245 juta ini butuh usaha keras bila ingin sukses. Per Januari 2013, Bank Indonesia menganggarkan 200 miliar rupiah untuk dana sosialisasi dengan masa 2 tahun.

Keempat, harga barang dan jasa dipastikan akan naik setelah redenominasi. Setelah redenominasi, harga barang terasa murah sehingga pengusaha bisa menaikkan harga jualnya. Misalnya, sebelum redenominasi harga semangkuk mie ayam adalah $\mathrm{Rp} 20.000$, setelah redenominasi menjadi Rp 20. Karena merasa nominal Rp 20 kecil, harga jual dinaikkan menjadi Rp 25 atau Rp 30. Imbasnya beban hidup masyarakat menjadi lebih mahal. Ujung-ujungnya akan terjadi inflasi lagi.

Kelima, pembulatan ke atas di awal pemberlakuan redenominasi. Efek ini hanya timbul di awal masa efektifnya saja. Bila pemerintah tidak mencetak uang logam pecahan kecil misalnya 1 sen, pedagang mungkin akan membulatkan kembalian, bisa terjadi kembalian terlalu banyak atau terlalu sedikit tergantung dari karakter penjual tersebut.

Keenam, masalah politik yang ada di balik redenominasi ini. Mungkin ada isu yang berbahaya yang bisa mengancam kredibilitas kelompok pejabat tertentu sehingga dibuat isu redenominasi ini. Sehingga perhatian masyarakat beralih ke redenominasi ini. Kita sebagai rakyat Indonesia yang mengerti "sedikit" politik telah sering memerhatikan sandiwara semacam ini, bahwa sering terjadi pengalihan isu.

Ketujuh, pemerintah harus mencetak uang kertas baru, uang logam baru, dan uang sen baru. Biaya pencetakan uang baru membutuhkan kertas baru,logam baru, desain baru dan mesin baru.

Kedelapan, masyarakat penghasilan bawahlah yang banyak menanggung efek rugi dari redenominasi ini. Di daerah masih banyak harga barang di bawah Rp 1.000. Jika terjadi redenominasi, ada kemungkinan harga-harga dinaikkan ke atas misalnya menjadi Rp 1 atau Rp 1.5. Pembulatan tersebut per unit memang kecil, tetapi ingat ada faktor pengali. Jika dikalikan dengan total unit, total pembulatan ke atas bisa mencapai triliunan rupiah.

Kesembilan, inflasi yang belum stabil. Memang secara keseluruhan inflasi Indonesia di bawah 5\%, tetapi ada bulan-bulan tertentu inflasi tinggi sekali, sehingga sebenarnya cukup rawan melakukan redenominasi di tahun 2013.

Kesepuluh, keresahan masyarakat. Masyarakat selalu mendapat informasi yang sepihak. Akibat informasi yang tidak lengkap membuat masyarakat mengambil kesimpulan yang salah. Akibatnya, hasil yang diharapkan oleh pemerintah tidak terjadi karena jumlah masyarakat yang ratusan juta dapat mengalahkan kemampuan pemerintah melaksanakan suksesnya denominasi. Yang dimaksud peneliti adalah pemerintah mengatakan redenominasi berbeda dengan sanering, tetapi 
masyarakat menganggap hal ini adalah sama. Akibatnya malah terjadi sanering meskipun uang tidak perlu digunting, namun nilai riil dari uang tersebut menurun drastis.

Melihat poin pertama sampai dengan kesepuluh, penulis ingin mengatakan "Daya Beli Masyarakat Golongan Menengah ke Bawah akan Menurun”. Hal itu berkaitan dengan pembulatan digit ke atas. Walaupun sudah dihimbau oleh pemerintah agar tidak menaikan harga barang/membulatkan harga ke atas, pada praktiknya selalu dilanggar. Sudah menjadi tradisi - bila tidak mau dikatakan membudaya - bahwa masyarakat Indonesia sering dan merasa bangga bila melanggar peraturan. Seperti halnya naik motor di area pejalan kaki, ataupun juga jalur bus transjakarta yang sering kali dipakai oleh kendaraan pribadi. Melanggar aturan ini dilakukan di hampir semua strata ekonomi.

\section{Syarat Redenominasi dapat Berjalan dengan Baik}

Menurut Setioko dalam Hutauruk (2011), syarat Redenominasi yang baik adalah poin 1 sampai dengan 3 dan disempurnakan oleh Martowardojo (2012) dari poin 1 sampai dengan point 4. Poin-poin tersebut, yaitu: (1) inflasi stabil di bawah 5\% selama 4 tahun berturut-turut; (2) negara memiliki cadangan devisa 100-200 miliar; (3) persamaan persepsi antara pemerintah/parlemen dan masyarakat yang di dalamnya meliputi pengusaha dan konsumen; dan (4) landasan hukum yang kuat untuk menjalankan program tersebut.

Redenominasi dapat dilakukan pada saat kondisi ekonomi baik dan inflasi terkendali. Dengan demikian, diharapkan tidak terjadi keresahan masyarakat yang oleh sebab itu masyarakat harus mempunyai kontrol harga terhadap barang/jasa. Hal ini dapat dilakukan dengan memberi dua harga yaitu harga sebelum redenominasi dan harga setelah redenominasi.

Adapun data inflasi Indonesia menurut data Bank Indonesia (Bank Indonesia, n.d.) adalah sebagai berikut.

Tabel 1 Daftar Inflasi Berdasarkan Indeks Harga Konsumen (Jan 2009 - Des 2012)

\begin{tabular}{lclc}
\hline \multicolumn{1}{c}{ Month / Year } & Inflation & \multicolumn{1}{c}{ Month / Year } & Inflation \\
\hline December 2012 & $4.30 \%$ & December 2011 & $3.79 \%$ \\
November 2012 & $4.32 \%$ & November 2011 & $4.15 \%$ \\
October 2012 & $4.61 \%$ & October 2011 & $4.42 \%$ \\
September 2012 & $4.31 \%$ & September 2011 & $4.61 \%$ \\
August 2012 & $4.58 \%$ & August 2011 & $4.79 \%$ \\
July 2012 & $4.56 \%$ & July 2011 & $4.61 \%$ \\
June 2012 & $4.53 \%$ & June 2011 & $5.54 \%$ \\
May 2012 & $4.45 \%$ & May 2011 & $5.98 \%$ \\
April 2012 & $4.50 \%$ & April 2011 & $6.16 \%$ \\
March 2012 & $3.97 \%$ & March 2011 & $6.65 \%$ \\
February 2012 & $3.56 \%$ & February 2011 & $6.84 \%$ \\
January 2012 & $3.65 \%$ & January 2011 & $7.02 \%$ \\
\hline \multicolumn{1}{c}{ Month / Year } & Inflation & \multicolumn{1}{c}{ Month / Year } & Inflation \\
\hline December 2010 & $6.96 \%$ & December 2009 & $2.78 \%$ \\
November 2010 & $6.33 \%$ & November 2009 & $2.41 \%$ \\
October 2010 & $5.67 \%$ & October 2009 & $2.57 \%$ \\
September 2010 & $5.80 \%$ & September 2009 & $2.83 \%$ \\
August 2010 & $6.44 \%$ & August 2009 & $2.75 \%$ \\
July 2010 & $6.22 \%$ & July 2009 & $2.71 \%$ \\
June 2010 & $5.05 \%$ & June 2009 & $3.65 \%$ \\
May 2010 & $4.16 \%$ & May 2009 & $6.04 \%$ \\
April 2010 & $3.91 \%$ & April 2009 & $7.31 \%$ \\
\hline
\end{tabular}




\begin{tabular}{llll}
\hline March 2010 & $3.43 \%$ & March 2009 & $7.92 \%$ \\
February 2010 & $3.81 \%$ & February 2009 & $8.60 \%$ \\
January 2010 & $3.72 \%$ & January 2009 & $9.17 \%$ \\
\hline
\end{tabular}

Adapun data cadangan devisa negara Republik Indonesia per September 2011 sebesar USD114.5 miliar (www.ekon.go.id), per akhir April 2012 sebesar USD 116.41 miliar (www.finance.detik.com), per akhir Desember 2012 sebesar USD 112.78 miliar (www.kominfonewscenter.com). Cadangan devisa negara dapat diperbesar dengan cara menarik investor asing menanamkan modal di Indonesia, surplus perdagangan dan memperbaiki keseluruhan ekonomi. Mengacu pada persyaratan yang ada, maka Bank Indonesia akan melakukan redenominasi Rupiah. Diharapkan redenominasi tersebut berjalan sesuai rencana.

\section{Negara-negara Lain yang Berhasil Melakukan Redenominasi}

Pertama, Turki; Turki melakukan redenominasi lira dengan memangkas 6 digit nol pada 2005. Kedua, Romania; Romania melakukan redenominasi lei dengan memangkas 4 digit nol pada 2005. Ketiga, Polandia. Polandia melakukan redenominasi zloty dengan memangkas 4 digit nol pada 1995. Keempat, Ukrania. Ukrania melakukan redenominasi hryvnia dengan memangkas 5 digit nol pada 1996. Kelima, Bulgaria; Bulgaria melakukan redenominasi lev dengan memangkas 3 digit nol pada 1999. Keenam, Brazil; Brazil menghilangkan 18 digit nol dalam 6 kali redenominasi yang terjadi pada 1967, 1970, 1986, 1989, 1993, 1994.

\section{Belajar dari Pengalaman Masa Lalu}

Pada 1950, 1959, dan 1965 Indonesia pernah melakukan sanering (pemotongan mata uang), dan ketiga proses tersebut gagal total, membuat ekonomi makin hancur dan terpuruk, membuat masyarakat menjadi miskin. Kondisi ekonomi Indonesia pada saat itu memang sedang buruk, utang pemerintah menumpuk dan inflasi tinggi. Sanering dalam bahasa Belanda berarti penyehatan, pembersihan, reorganisasi. Akan tetapi, bagi masyarakat Indonesia yang saat ini berusia 60 tahunan, kejadian 3 kali pemotongan uang masih membuat trauma dan ketakutan. Hampir semua warga negara yang berusia 60 tahun ke atas ini mencemaskan bahwa redenominasi ini merupakan semacam sanering terselubung.

\section{SIMPULAN}

Menurut peneliti, kebijaksanaan pemerintah untuk melakukan redenominasi bisa dilakukan namun harus berhati-hati dalam pelaksanaannya, Kepentingan rakyat banyak harus didahulukan supaya keadilan dan kesejahteraan masyarakat Indonesia bisa lebih merata. Sebenarnya masih banyak lagi hal yang perlu diperhatikan pemerintah ketimbang redenominasi, seperti bencana alam banjir dan longsor, pengerukan Sumber Daya Alam (Batu Bara, Nikel, Emas) yang sewenang-wenang tanpa izin jelas, penggundulan hutan tanpa izin jelas, pengentasan buta huruf di desa-desa pelosok, masalah kesehatan di pelosok desa, masalah anak putus sekolah dan terpaksa harus bekerja bersama orangtua. Hal-hal tersebut lebih "mendesak" penanganannya.

Sosialisasi harus berhasil jika pemerintah ingin menyukseskan program redenominasi ini. Karena dengan adanya sosialisasi yang baik, akan meningkatkan kesadaran masyarakat alasan terjadi redenominasi sehingga tidak menyalahkan pemerintah atas program ini. Sosialisasi yang baik harus memberi informasi yang jelas, akurat, dan gampang diakses. Selain itu, sosialisasi dapat dilakukan melalui berbagai media atau tatap muka dengan representatif dari lembaga pemerintah yang 
bertanggung jawab, apakah itu dari instansi Bank Indonesia, Departemen Keuangan, atau universitas yang membantu terlaksananya program ini.

Sanering memang tidak sama dengan redenominasi dalam teori, tetapi dalam praktiknya akan menjadi sama karena akan membuat nilai mata uang di Indonesia turun perlahan. Ujung-ujungnya, pengusaha swasta dan masyarakat yang akan menanggung beban hidup yang makin berat karena kenaikan gaji tidak berimbang dengan kenaikan harga-harga barang/jasa. Hal ini bila dibiarkan terus menerus tanpa perhatian serius dan kebaikan hati para pejabat negara akan membuat pengangguran terbuka di Indonesia.

Kemudian akan terjadi dua hal. Pertama yaitu apabila keluarga mempunyai modal keuangan yang lebih baik, akan melakukan migrasi ke luar negeri karena di luar Indonesia menjanjikan kehidupan yang lebih baik, pendapatan yang lebih baik, hak asasi manusia yang lebih manusiawi. Hal yang kedua adalah mereka yang kurang beruntung dalam masalah keuangan akan tetap tinggal di Indonesia dan mencari cara yang instan misalnya korupsi, mencuri, dan melakukan tindak kriminal. Yang pada akhirnya, penduduk Indonesia akan dipenuhi mayoritas WNI yang kurang bermoral, kurang berakhlak yang baik padahal negara kita adalah negara yang beragama. Pancasila sudah tidak bisa menjadi ideologi dasar, banyak rakyat sudah lupa dengan 36 butir Pancasila. Menyedihkan sekali kondisi yang akan terjadi jika kehidupan masyarakat Indonesia jauh dari ideologi Pancasila. Peneliti mengajak kepada para pendidik untuk selalu memberikan contoh yang baik untuk para mahasiswa supaya nilai-nilai luhur Pancasila tidak hilang, tidak luntur. Kepentingan pribadi ataupun golongan dikesampingkan untuk membuat negara Indonesia makmur dan maju. Dengan demikian, pada saat para mahasiswa lulus dari perguruan tinggi, mahasiswa tersebut mempunyai karakter yang baik, membela bangsa dan negara, selalu mau memajukan negara Indonesia tercinta.

Sebagai saran, peneliti berpandangan bahwa pemerintah sebaiknya serius dalam menggarap program redenominasi ini agar kesejahteraan masyarakat golongan bawah tidak terus menderita.

\section{DAFTAR PUSTAKA}

Anonim. (2011). Kajian tentang rencana Redenominasi Rupiah Dalam Sistem Keuangan Jangka Panjang Di Indonesia. Volume 2 Nomor 01 (2011). Diakses 7 Februari 2013 dari http://ejournal-unisma.net/ojs/index.php/jrak/article/download/62/60.

Bank Indonesia. (n.d.). Laporan Inflasi (Indeks Harga Konsumen): Berdasarkan Perhitungan Inflasi Tahunan. Diakses 11 Juli 2013 dari http://www.bi.go.id/biweb/Templates/Moneter/Default_Inflasi_ID.aspx?NRMODE=Published \&NRNODEGUID $=\{$ A7760121-1768-4AE8-B333-

0C91E746F1E3\}\&NRORIGINALURL=\%2fweb\%2fid\%2fMoneter\%2fInflasi\%2fData\%2bIn flasi\%2f\&NRCACHEHINT=Guest

Basri, F., Munandar, H. (2009). Lanskap Ekonomi Indonesia. Jakarta: Kencana Prenada Media Group.

Calomiris, C. (2006). Devaluation with Contract Redenomination in Argentina. NBER Working Paper Series. Columbia University, USA. Diakses 8 Februari 2013 dari http://academiccommons.columbia.edu/download/fedora_content/download/ac:137015/CONT ENT/w12644.pdf

Farlex,(2013),The Free Dictionary, Financial Dictionary(Online).diakses pada tanggal 9 February 2012. www.financial-dictionary.thefreedictionary.com/Redenominasi. 
Hutauruk, P. J. P. (2011). Redenominasi Nilai Mata Uang Rupiah dalam Keuangan Negara. Universitas Andalas. Diakses $8 \quad$ Februari 2013 dari http://pahalajunedipandapotanhutauruk.blogspot.com/2012/06/redenominasi-nilai-mata-uangrupiah.html

Lianto, J., Suryaputra, R. (2012). The Impact of Redenomination in Indonesia from Indonesian Citizens' Perspective. Elsevier. Volume 40, 2012 pages 1-6. Diakses 7 Februari 2013 dari http://www.sciencedirect.com/science/article/pii/S1877042812006209.

Martowardojo, A. (2013). Menteri Keuangan Republik Indonesia periode 2010-2014. Dalam acara Kick Off Konsultasi Publik Perubahan Harga Rupiah Redenominasi pada tanggal 23 Januari 2013.

McConnell, C. R., Brue, S. L. (2008). Economics Principles, Problems, and Policies. Singapore: Mc Graw-Hill.

Mosley, L. (2005). Dropping Zeros, Gaining Credibility? Currency Redenomination in Developing Nations. US: University of North Carolina, Amerika Serikat. Diakses 7 Februari 2013 dari http://www.unc.edu/ lmosley/APSA\%202005.pdf

Nugroho,Primawan W.,Basuki, Maruto U.(2012).Analisis Faktor-Faktor yang mempengaruhi Inflasi di Indonesia periode 2000.1-2011.4(Online).Diponegoro Journal of Economics. Volume 1 No 1 Tahun 2012. Halaman 1-10.diakses tanggal 9 Februari 2013 dari http://ejournals1.undip.ac.id/index.php/jme/article/view/640/639 